\title{
The challenges of aligning aggregation schemes with equitable fruit and vegetable delivery: lessons from Bihar, India
}

Gregory S. Cooper

Institute for Sustainable Food, The University of Sheffield, Sheffield, UK

Karl M. Rich

West Africa Regional Office, International Livestock Research Institute (ILRI), Dakar, Senegal

Bhavani Shankar

Institute for Sustainable Food, The University of Sheffield, Sheffield, UK, and

Vinay Rana

Transform Rural India Foundation (TRIF), Raipur, India

\begin{abstract}
Purpose - Agricultural aggregation schemes provide numerous farmer-facing benefits, including reduced transportation costs and improved access to higher-demand urban markets. However, whether aggregation schemes also have positive food security dimensions for consumers dependent on peri-urban and local markets in developing country contexts is currently unknown. This paper aims to narrow this knowledge gap by exploring the actors, governance structures and physical infrastructures of the horticultural value chain of Bihar, India, to identify barriers to using aggregation to improve the distribution of fruits and vegetables to more local market environments.

Design/methodology/approach - This study uses mixed methods. Quantitative analysis of market transaction data explores the development of aggregation supply pathways over space and time. In turn, semistructured interviews with value chain actors uncover the interactions and decision-making processes with implications for equitable fruit and vegetable delivery.

Findings - Whilst aggregation successfully generates multiple producer-facing benefits, the supply pathways tend to cluster around urban export-oriented hubs, owing to the presence of high-capacity traders, large consumer bases and traditional power dynamics. Various barriers across the wider enabling environment must be overcome to unlock the potential for aggregation to increase local fruit and vegetable delivery, including informal governance structures, cold storage gaps and underdeveloped transport infrastructures.

Originality/value - To the best of the authors' knowledge, this study is the first critical analysis of horticultural aggregation through a consumer-sensitive lens. The policy-relevant lessons are pertinent to the
\end{abstract}

(c) Gregory S. Cooper, Karl M. Rich, Bhavani Shankar and Vinay Rana. Published by Emerald Publishing Limited. This article is published under the Creative Commons Attribution (CC BY 4.0) licence. Anyone may reproduce, distribute, translate and create derivative works of this article (for both commercial and non-commercial purposes), subject to full attribution to the original publication and authors. The full terms of this licence may be seen at http://creativecommons.org/licences/by/4.0/legalcode

The authors gratefully acknowledge financial support from the Market Intervention for Nutritional Improvement (MINI) project funded by the Bill and Melinda Gates Foundation (BMGF) and the UK Government's Foreign, Commonwealth and Development Office (FCDO) (Grant No. OPP1182694). The views expressed in this work are those of the creators and do not necessarily represent those of BMGF, FCDO or Digital Green. The authors additionally recognise the valuable contributions of Pawan Ojha and Rikin Gandhi towards the organisation and management of the 2018 field campaign, and Shailesh Tiwary and Sasmita Nayak for their assistance with interviews and translation throughout 2018

Declaration of interest: No potential conflict of interest was reported by the authors.
Equitable aggregation schemes

Received 27 November 2020 Revised 22 February 2021 Accepted 7 April 2021 
JADEE 12,2 equitable and sustainable development of horticultural systems both in Bihar and in similar low- and middleincome settings.

Keywords Horticulture, Value chain, Markets, Trade-offs, Mixed methods

Paper type Research paper

\section{Introduction}

Consistent with Agenda 2030 for Sustainable Development (UN, 2015), there is increasing recognition that food systems and their value chains should benefit the spectrum of society (FAO, 2014). However, inadequate access to nutritious foods such as fruits and vegetables $(\mathrm{F} \& \mathrm{~V})$, vital in the combat against multiple forms of cancer, cardiovascular disease and allcause mortality (Aune et al., 2017), is often marked by inadequate availability, a lack of nutritional awareness amongst consumers and disempowerment (Hawkes and Ruel, 2011; Maestre et al., 2017). As such, food value chain interventions must become more responsive to the needs of vulnerable populations (Gelli et al., 2015; Hawkes and Ruel, 2011), including how distributional pathways, market governance and consumer preferences influence the equitable delivery of healthy and nutritious foods.

Improving the supply of F\&V to markets is generally considered to be an important first step in improving their consumption amongst populations with seasonal or perennial barriers to access (Hawkes and Ruel, 2008). Development practice has long experience with market systems "upgrades" that have the potential to improve supply and financial returns to specific value chain actors (Devaux et al., 2018; Fischer and Qaim, 2012). Such interventions have a chequered history in India, where the median daily intake of $\mathrm{F} \& \mathrm{~V}$ was recently estimated to be $50 \%$ of the World Health Organization's (WHO) $400 \mathrm{~g} / \mathrm{capita} /$ day recommendation (Choudhury et al., 2020), with rural F\&V consumption potentially as low as $160 \mathrm{~g} /$ capita/day (Minocha et al., 2018). Although national F\&V production has tripled since the 1990 s, retail prices have not responded proportionately (Rahman, 2012). Moreover, the introductions of intensification technologies have been challenged by poor technological know-how, unreliable extension efforts and the reluctance to give up traditional cultivation and marketing techniques (Kumari et al., 2017; World Bank, 2007). Further downstream, only $0.3 \%$ of the national cold chain capacity stored F\&V in 2011 (Halder and Pati, 2011), with wastage rates between farm and fork estimated to be up to 30-40\% (Minocha et al., 2018; Narula, 2011).

Therefore, based around a producer-oriented horticultural aggregation scheme in Bihar, India, we ask what are the opportunities and barriers facing supply-enhancing value chain upgrades in the improvement of F\&V deliveries to low-capacity, infrastructurally underdeveloped markets in often isolated localities? From this central research question, we also make three contributions to the existing literature.

First, aggregation schemes are principally farmer-facing interventions: bulking, transporting and marketing agricultural supplies to provide convenience and reduce transaction costs for multiple farmers (Shepherd, 2018). Through vehicle access, aggregation may also open up markets which were previously inaccessible to smallholders (Wiggins and Compton, 2016). However, despite their potential benefits, aggregation schemes are underrepresented in the literature relative to other forms of market upgrades (Hainzer et al., 2019). Where documented, aggregation schemes often involve high-input subsidies, for example, in the provision of expensive seeds in Ugandan Afro-Kai sorghum aggregation (World Bank, 2018) and the provision of cold storage in vegetable aggregation in Tamil Nadu, India (Govil et al., 2014). In the case of the Indian Samriddhii scheme, heavily subsidised transport attempted to bypass the network of market middlemen, only to find that farmers valued the loans and inputs provided by the same middlemen (Anjalay and Bhamoriya, 2011). We aim to widen the limited body of evidence around the characteristics of aggregation schemes that influence the flows of $\mathrm{F} \& \mathrm{~V}$, information and finance in developing country contexts. 
Second, previous research into aggregation tends to trace the value chain as far as the market - meaning downstream impacts, and particularly the implications for consumers, remain unexplored. Where analysis exists (e.g. Kubzansky et al., 2011; Wiggins and Compton, 2016), aggregation schemes are found to predominantly supply large, top of the chain buyers - such as supermarkets and processing facilities - owing to the supply of high quality in bulk and over long distances. Therefore, we chase the value chain downstream of the first buyer, to explore whether any increases in supply or the reorganisation of distribution associated with aggregation has potential implications for $\mathrm{F} \& \mathrm{~V}$ availability for access-vulnerable consumers.

Third, and based upon the identification of value chain barriers and opportunities, we scope potential future scenarios that may help to align aggregation with the needs of the wider population to access affordable F\&V. Our analysis, based on the "Loop" aggregation scheme of the non-governmental organisation Digital Green in Bihar (Figure 1), continues the drive to develop such studies from one-time snapshots to integrated assessments of the structures, feedbacks and leverage points that underpin our food systems (Devaux et al., 2018; Orr and Donovan, 2018).

The next section contextualises Loop within its horticultural system, before Section 3 outlines the rapid value chain analysis (VCA) approach. Section 4.1 describes the value chain and its constraints upon the equitable delivery of $\mathrm{F} \& \mathrm{~V}$, before Section 4.2 analyses the evolution of Loop over both space and time. We finish by discussing (1) the issues practitioners may face when grappling with the consumer-facing dimensions of aggregation, (2) the scenarios that may improve the equitable F\&V delivery of aggregation, (3) the wider contributions and limitations of our approach.

\section{Loop within the horticultural context of Bihar}

Bihar has the lowest GDP per capita of all Indian states, with an estimated $34 \%$ of the population earning less than $\$ 1.25 /$ day (World Bank, 2016). Whilst Bihar is the third largest producer of vegetables and eighth largest producer of fruits amongst Indian states, approximately $70 \%$ of vegetable production originates from small (1-2 ha) or marginal $(<1 \mathrm{ha})$ landholdings (Sinha and Kumar, 2015). As of 2012, the average per capita F\&V consumption rate was approximately $35-45 \%$ of the WHO's recommended $400 \mathrm{~g} / \mathrm{capita} / \mathrm{day}$ (NSSO, 2013), with rural consumption roughly $12 \%$ less than urban.

\section{Equitable aggregation schemes}

225

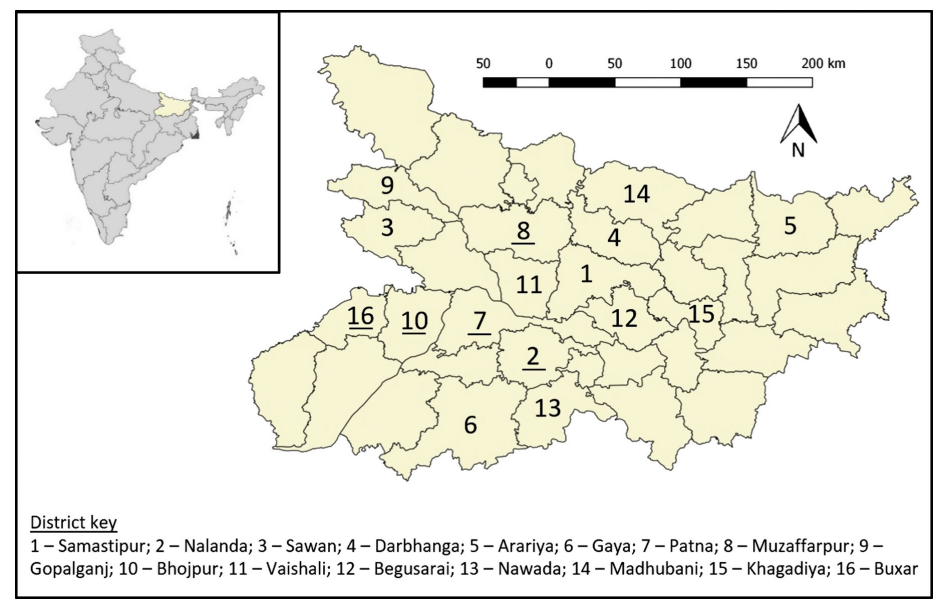

Figure 1.

The districts of Bihar (inset - yellow) that have supplied Loop with $\mathrm{F} \& \mathrm{~V}$ between January 2016 and September 2018. The districts are ordered by the date of first aggregation (2nd January 2016-1st November 2017). Primary data was collected from the underlined districts 
JADEE 12,2

226
Horticultural marketing is predominantly traditional, informal and unregulated (Kumari et al., 2020; World Bank, 2007). The vast majority of $\mathrm{F} \& \mathrm{~V}$ production is sold fresh, with the state's 290 cold storage units "almost exclusively used for the storage of potato" (Minten et al., 2011, p. 5). Bihar's horticultural system is therefore characterised by a network of marginal landholdings and production systems that are vulnerable to climate-driven losses, seasonality and wastage. Moreover, financially poor consumers and underdeveloped transport infrastructures magnify upstream barriers to further suppress downstream F\&V availability.

Against this backdrop, Digital Green launched the Loop aggregation scheme in January 2016, with the explicit aims of pooling F\&V produce to cut transport costs, negotiate higher prices, save marketing time and increase market access and information for farmers (Digital Green, 2017). Each participating cluster of 3-4 neighbouring villages has a vehicle-owning aggregator, who either directly supplies market traders through prearrangement or enters into spot negotiations with commission agents known locally as "gaddidars."

Beyond the coordination of supplies from over 28,000 farmers, Loop also provides various technology-based innovations relative to traditional collective marketing methods (e.g. the hiring of public transport). Rather than hailing a bus or an autorickshaw at the roadside, farmers can reserve market transport by contacting their aggregator one day in advance. Aggregators record various market transaction details in the Loop smartphone application (e.g. market name, quantity sold and per unit price), which provides farmers with a digital receipt of past transactions. In turn, farmers and aggregators have access to a market price telephone "hotline" to aid transparency and price discovery. Although aggregators do not formally backhaul $F \& V$ or inputs to the villages under Loop, they often pursue other transporting and/or marketing work once a buyer has been found for their aggregation. Moreover, the market-bound transport costs aggregators incur are subtracted from the farmers markets revenues, and Digital Green as a not-for-profit organisation also remunerates aggregators with an additional $0.1 \mathrm{Rs}$ per $\mathrm{kg}$ aggregated.

However, according to "Loop dashboard" data (Section 3.2), the 80,500 tonnes of F\&V aggregated between January 2016 and September 2018 was highly skewed towards urban wholesale markets, with $58.0 \%$ of total supplies delivered to only ten horticultural markets (out of 105 supplied in total). Therefore, given the potential for aggregation to coordinate smallholders and influence market supplies, it is important to investigate (a) the value chain functions, priorities and vested interests that may undermine efforts to improve $\mathrm{F} \& \mathrm{~V}$ delivery to access-vulnerable consumers, and (b) consider potential interventions that may overcome such barriers to co-produce benefits for aggregating farmers and small market consumers.

\section{Materials and methods}

This rapid VCA encompasses Loop within the horticultural value chain of Bihar, including the actors and operations downstream of markets that process, store and/or add value en route to consumers (Kaplinsky and Morris, 2001). We integrate qualitative data from stakeholder interviews and quantitative data from the "Loop dashboard" (publicly available: www.loopapp.org/loop/analytics). Prior to data collection, ethical clearance was obtained from the ethics board of the university leading the research.

\subsection{Primary data}

We conducted 49 interviews with actors across the value chain (Table 1). With Loop only registering transactions in Buxar since November 2017, the first round of interviews (AprilMay 2018) focussed on perceptions of recent changes to farming activities, marketing habits 
and livelihood outcomes, relative to their activities prior to Loop membership (Appendix 1). The second phase of interviews (August-September 2018) focussed on the procurement and trading activities of actors facing downstream of $\mathrm{F} \& \mathrm{~V}$ markets (Appendix 1). To capture heterogeneity in downstream pathways, interviews were split between the districts of Buxar, Bhojpur, Nalanda, Patna and Muzaffarpur (Figure 1).

Participants were co-selected with Digital Green, using purposeful and snowball sampling to select actors with rounded knowledge of Loop and/or their specific value chain segment. Rather than being designed for statistical representativeness, the interviews aimed to map the range of actors and decision-making processes driving $\mathrm{F} \& \mathrm{~V}$ between farm and fork, as well as narratives around how aggregation has introduced changes to the value chain. Whilst focussing on the participant's specialist knowledge, the interview scripts retained flexible structures to allow any narratives of particularly interest to be followed. Informed consent was sought before each interview, with additional consent sought before audio recordings. Interviews lasted 45-60 min and were recorded in Hindi before a research assistant from Digital Green assisted with English translation.

We acknowledge the potential limitations of our sampling strategy, namely the selection of only Loop farmers and the pressure they may have felt to give positive accounts of aggregation. All farmers selected had accrued most of their farming experience before joining Loop, with the aggregation scheme introduced no more than 2 years before the interviews took place. Therefore, the farmers interviewed were qualified to speak about the non-Loop aspects of the value chain, as well as any perceived changes to production, marketing and trading activities. Prior to the interviews, all actors were notified that neither their participation nor responses would affect their aggregation participation, with all interviews anonymised at the point of transcription. All questions were neutrally framed to avoid leading the interviewee into making a critical judgement of Loop.

\subsection{Secondary data}

A particularly valuable resource available to this research is the "Loop dashboard", which provides a near real-time record of market transactions (i.e. the sale of one vegetable product from one Loop farmer, represented by an aggregator, to one market buyer). The dashboard contains over 700,000 transactions at the time of writing (mid-2020), including the F\&V type, quantity, per unit price and financial revenue of each transaction, alongside the locations of markets and producer villages. The database also contains metadata detailing additional value chain dimensions, including the gender of Loop farmers, the cost of aggregation and the type of aggregation vehicle used. However, the dashboard does not track produce beyond the first buyer, highlighting the need for qualitative data downstream of markets.

The dashboard is standalone in its systematic collection of market data in Bihar. The Government of Bihar publishes annual reports with crop-wise production volumes that are aggregated to the state level over the last 12 months (GoB, 2019). In turn, the AgMarket portal

\begin{tabular}{lccccccr}
\hline Participant & Phase & Bhojpur & Buxar & $\begin{array}{c}\text { District name } \\
\text { Muzaffarpur }\end{array}$ & Nalanda & Patna & Totals \\
\hline Loop farmer & 1 & - & 14 & - & - & - & 14 \\
Aggregator & 1 & - & 4 & - & - & - & 4 \\
Commission agent & 1 & - & 2 & - & - & - & 2 \\
Inter-market wholesaler & 2 & - & 1 & 1 & 2 & - & 4 \\
Retailer & 2 & - & 4 & 2 & 3 & 8 & 17 \\
Consumer & 2 & 1 & 3 & 1 & 3 & - & 8 \\
Totals & & 1 & 28 & 4 & 8 & 8 & 49 \\
\end{tabular}

Equitable aggregation schemes

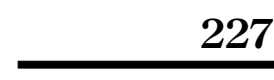


JADEE 12,2

228

(http://www.agmarknet.gov.in/) of the Directorate of Marketing \& Inspection (DMI) purports to collect commodity-wise price and arrival statistics across all of India's 28 states and eight union territories; however, at the time of writing, no data exists for any of the vegetables aggregated in the study districts. Lastly, the "MIS Daily Report" of the National Horticultural Board (http://www.nhb.gov.in/OnlineClient/MISDailyReport.aspx) provides daily statistics for $26 \mathrm{~F} \& \mathrm{~V}$ types arriving at markets across Indian state capitals; however, the report lacks the metadata needed to meaningfully interpret the time series (e.g. market names and number of transactions). Therefore, comparative analysis of Loop and non-Loop outcomes is constrained by the lack of quantitative data from the wider value chain. Consequently, quantitative analysis focusses on how the spatiotemporal development of Loop may reinforce or overcome the value chain barriers to adequate $\mathrm{F} \& \mathrm{~V}$ delivery.

Dashboard data was obtained from Digital Green in CSV format and analysed in the statistical software R (2013). To visualise village to market aggregation supply pathways (Section 4.2), the georeferenced dashboard data was processed in the Geographical Information System "QGIS."

\section{Results}

\subsection{Barriers and opportunities across the wider value chain}

4.1.1 Traditional supply pathways. As aggregation schemes do not exist in isolation, we first identify the actors, pathways and governance settings of the wider chain, focussing on the decisions and processes with implications for aggregation and the potential to achieve F\&V delivery outcomes.

Whilst the horticultural value chain takes various local forms, F\&V production generally flows downstream from farms to consumers via channels of agents, inter-market traders and retailers (Figure 2). These channels are unregulated, informal and almost entirely dependent on trust-based relationships. Farmers traditionally self-supply markets on foot, bicycle or autorickshaw. At the market, farmers meet with commission agents at traditional "gaddidar markets" or direct with downstream buyers at "farmers markets" (i.e. without gaddidars). Farmers could also meet with government agents during the operational years of the Agricultural Produce Marketing Committee (APMC); however, the act was repealed in Bihar in 2006 to deregulate marketing activities.

Furthermore, farmers may sell to farmgate traders who purchase from multiple farmers within one village. To attract supplies during the lean season (e.g. June-August, Appendix 3), traders specialising in major crops such as tomato, cauliflower and cabbage may offer rates of Rs $2-3 / \mathrm{kg}(8-12 \%)$ higher than the local market. However, these farmgate traders tend to offer prices of 1-2 Rs/kg (12-25\%) lower than markets during supply highs (e.g. DecemberMarch), knowing that farmers want to conveniently "dump produce that might not sell" otherwise (Farmer 2, Buxar district) [1].

4.1.2 Commission agents. The primary function of a gaddidar is to connect upstream sellers with downstream buyers in exchange for a commission, which generally ranges between $1-7 \%$ of the transaction value. Gaddidars may also then charge the buyer for fixing the transaction, with local traders charged the same as the farmer and traders from external markets charged up to double the local rate.

With gaddidar commissions subtracting from farmer revenues and ultimately inflating retail prices, we found debate amongst farmers and aggregators as to whether gaddidars are beneficial. For example, two farmers in Buxar district expressed a preference for markets with gaddidars, who are perceived to take "considerable financial and reputational risk on behalf of farmers" (Farmer 2). In contrast, farmers markets in towns such as Dumri (Buxar) and Ganj Bazar (Muzaffarpur) allow farmers, retailers and traders to interact directly. Aggregator 3 (Ganj Bazar) reasoned that farmers markets "benefit every stage of the chain from producer to 

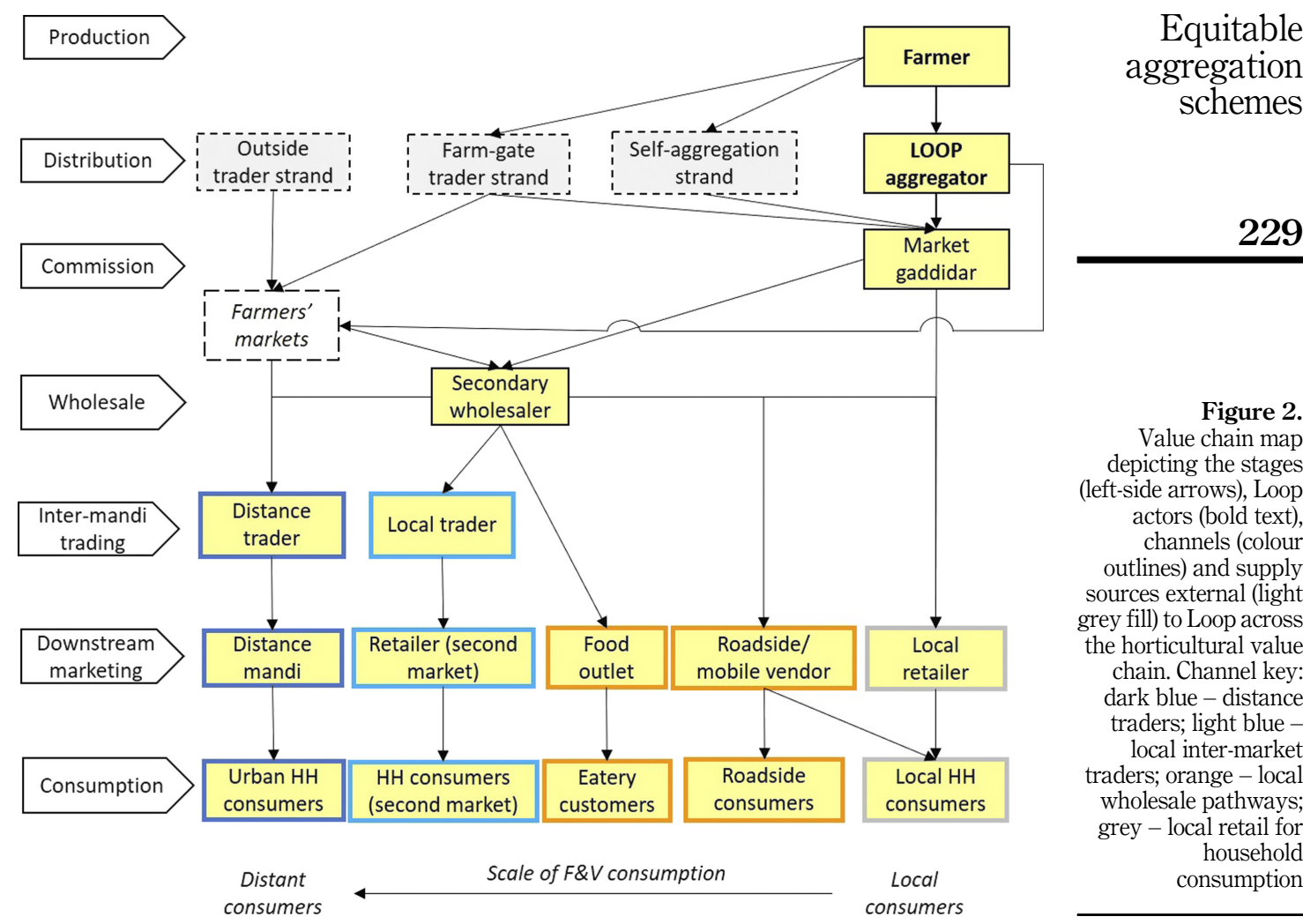

consumer" because farmers and traders do not pay commission, traders can purchase perishable products directly at source and consumers welcome lower retail prices from fewer intermediaries. However, the reluctance of local retailers to purchase in bulk means that aggregators risk being left with unsellable produce. Furthermore, the tendency for smaller transactions can cause traders to offset the costs of wastage by inflating their margins by 1-3 $\mathrm{Rs} / \mathrm{kg}$ - with negative implications for downstream consumer-facing affordability.

Where present, gaddidars play a central role in value chain governance, conceptualised as the ability to influence relationships between different actors (Gereffi et al., 2005). For new entrants into the market, transactions often conform to market-based governance, owing to the ad-hoc nature of buyer-seller interactions and the low financial costs of switching relationships. However, mature, long-term relationships that form between farmers/ aggregators and gaddidars resemble relational governance structures. Despite the absence of formal contracts, mutual dependence is harboured as gaddidars are the main source of market knowledge and price information. Moreover, gaddidars provide an independent assessment of $\mathrm{F} \& \mathrm{~V}$ quality - highly valued by farmers without the know-how or infrastructure to grade produce before the market. Therefore, the security provided by gaddidars helps to entrench village to market pathways, with the interviewed farmers generally prioritising the maintenance of business and social relationships above short-term price benefits.

Gaddidars may also provide storage and/or loans to farmers to purchase inputs such as seeds and fertilisers, in agreement that the farmer will then supply the gaddidar in future. The 
JADEE 12,2

\section{0}

interviewed gaddidars tended not to charge interest, recognising that "debt-laden farmers would struggle to purchase inputs" (Gaddidar 1, Buxar district), which would feedback to harm commission generation. Therefore, whilst Loop does not require farmers to supply particular vegetables, having potentially positive implications for the diversity of $\mathrm{F} \& \mathrm{~V}$ available at both the farm and market levels, the flexibility to supply different markets is affected by pre-existing relationships between farmers and gaddidars. This rigidity may be further compounded by the difficulties associated with market entry, with Farmer 5 (Buxar district) estimating that it may take "more than ten profitable transactions to build trust between buyer and seller".

4.1.3 Inter-market traders. Inter-market traders may be categorised into distance and local traders, with the former purchasing F\&V from local markets to sell outside of their district and/or state, and the latter operating solely around neighbouring markets. Traders also transport different F\&V quantities; for example, distance traders in Bihar Sharif (Nalanda) export up to $30,000 \mathrm{~kg} /$ day during the local high season, while local traders may handle between 2,200 and 2,500 kg/day. These capacities are partly a function of the type of vehicle used, with distance traders typically employing pickup, flatbed or "all-India permit" goods trucks (2,000-5,000 kg capacities); in contrast, local traders mainly rely on public transport or privately owned vehicles ( $500 \mathrm{~kg}$ capacities). Consequently, distance traders only operate from markets with sufficient F\&V supplies, infrastructure and physical space, which tend to be located in district capitals.

Distance traders also influence market price formation by basing their buying price on the price they expect to receive at the distance market; for example, in cities such as Patna, Asansol and Kathmandu, the expected price can be " $20 \mathrm{Rs} / \mathrm{kg}$ higher than second-tier urban markets in Bihar" (Trader 2, Muzaffarpur district). Distance traders may also seasonally adapt their sources and destinations to keep margins competitive. For example, in August 2018, Trader 1 in Dumraon (Buxar district) imported tomatoes from Maharashtra where prices fell to $2 \mathrm{Rs} / \mathrm{kg}$. Post-monsoon, the trader exported tomatoes to regions $200-300 \mathrm{~km}$ to the south for a $5-8 \mathrm{Rs} / \mathrm{kg}$ margin.

All three distance traders interviewed noted that the growth in production and supply over the past 5 years has been offset by an increasing number of traders. In parallel, the interviewed farmers perceived more competitive pricing and supply options, with the increasing export of $\mathrm{F} \& \mathrm{~V}$ by out-of-state traders potentially undercutting the availability and affordability of horticultural products in access-vulnerable local markets.

4.1.4 Retailers. Stationary market-based wholesalers tend to market F\&V quantities around $10 \mathrm{~kg}$ to commercially oriented customers, including traders, restaurateurs, grocery stores and roadside vendors, while retailers may sell $1-2 \mathrm{~kg}$ to individuals consuming $\mathrm{F} \& \mathrm{~V}$ at home. In peri-urban Bihar, local $\mathrm{F} \& \mathrm{~V}$ markets consist of 20-30 retailers, whilst rural village haats may consist of only 20 farmers retailing their own harvests to local consumers. Therefore, as the points of contact for relatively access-vulnerable consumers, $F \& V$ retailers are key to regulating the flows and prices of $\mathrm{F} \& \mathrm{~V}$ in peri-urban and rural markets.

Household consumers in Muzaffarpur and Buxar districts tend to visit twice-weekly retail markets (e.g. Wednesday and Sunday in Ganj Bazar, Muzaffarpur district), which are driven by self-organisation and coordination across the chain, as opposed to formal regulations. Retailer 4 in Buxar perceives retail markets as "win-wins for everyone", with consumers able to access a wider range of fresh $F \& V$ due to farmers targeting these days to boost their own revenues. However, access is not universal, with retailers increasing prices by $1-2 \mathrm{Rs} / \mathrm{kg}$ (5$10 \%$ ) above the wholesale price in response to heightened demands. Similarly, even on regular market days at Patna's Anta Ghat market, retailers were found to reduce prices by 4 $\mathrm{Rs} / \mathrm{kg}(15-20 \%$ ) for purchases of more than $1 \mathrm{~kg}$, reflecting the desires of retailers to attract small-scale traders (e.g. restaurateurs and vendors) to offset expected wastage from retail transactions. Therefore, even in urban areas, the elastic dynamics of retailers and local 
markets may have negative implications for the poorest consumers, with inflated prices restricting access to the full range of $\mathrm{F} \& \mathrm{~V}$.

Moreover, the same quantity of the same vegetable may be priced differently according to quality, with retailers in Nalanda, Buxar and Muzaffarpur arguing that customers consider $\mathrm{F} \& \mathrm{~V}$ shape, freshness and bruising when negotiating prices. The retailers interviewed stated that low-grade produce is generally priced up to $50 \%$ less than high-grade, which normally translates into a 5-10 Rs/kg difference. Compounded by the tendency of retailers to increase prices when small volumes are being purchased, financially constrained consumers often have to settle for F\&V that is relatively "less fresh and less tasteful" (Consumer 5 - Nalanda district) than local high-grade produce.

4.1.5 Consumers. Average F\&V consumption rates in Bihar are approximately $35-45 \%$ of the WHO benchmark of $400 \mathrm{~g} / \mathrm{capita} /$ day. Moreover, the consumption of nine of the NSSO's $15 \mathrm{~F} \& \mathrm{~V}$ groups declined in Bihar between 2005-2006 and 2011-2012 (including mangoes, leafy vegetables, gourds, carrots and "other vegetables"), whilst the consumption of tomato rose ten-fold, and the consumption of potato and "onion and garlic" increased by 18 and $10 \%$, respectively (NSSO, 2013). Reflecting wider consumption patterns in India (Minocha et al., 2018), these Bihar-specific trends suggest a drift away from the consumption of vegetables (from an already low baseline) towards relatively energy-dense food items.

The consumers interviewed shared numerous perceptions and preferences that may reinforce the upstream barriers to equitable $\mathrm{F} \& \mathrm{~V}$ delivery. Two consumers expressed a preference to shop at larger markets, with Consumer 4 (Buxar district) claiming that regional urban hubs such as Buxar offer "higher chances of negotiating, more vegetables, [and] more choice". Four of the consumers expressed a preference for local production, owing to the perceptions that local produce is "tastier" (Consumer 5, Muzaffarpur district), "fresher" (Consumer 6, Nalanda district) and "healthier" (Consumer 8, Nalanda district). The tendency for local production to be more expensive reflects these perceptions and reinforces the motivations of farmers to supply markets where consumers desire fresh local produce and have the financial means to afford their purchase.

In times when local varieties are unavailable and/or prices are high, consumers were found to (1) maintain the overall quantity purchased but increase the proportion of low-grade produce to "make money stretch further" (Consumer 1, Buxar district), (2) cut the purchase of fruits "when prices are high for a couple of days" (Consumer 7, Nalanda district) or (3) cut quantities but prioritise high-grade produce to "manage the price" (Consumer 6, Nalanda district). These coping mechanisms substitute quantity or quality in favour of affordability, with such trade-offs likely to be magnified where $\mathrm{F} \& \mathrm{~V}$ supplies are less reliable, storage facilities are unavailable and consumer purchasing power is relatively constrained.

\subsection{The spatiotemporal evolution of loop}

Building on the characteristics of the wider value chain, this section outlines the spatiotemporal evolution of the Loop aggregation system, before discussing its interactions with the barriers to improving $\mathrm{F} \& \mathrm{~V}$ delivery to access-vulnerable consumers.

4.2.1 Temporal evolution. Loop first established a diversity of aggregation products between January 2016 and June 2017 (Figure 3a), before dramatically intensifying aggregation quantities during the second half of 2017 (Figure 3b). This rapid intensification was triggered by both the five-fold increase in the number of farmers supplying Loop as the scheme expanded into Nawada, Khagadiya and Buxar districts and the timing of cauliflower, eggplant, tomato and cabbage harvests which are grown in high volumes across Bihar from October to March (Appendix 3).

The trends of per-farmer outcomes are more complex. Whilst the average supply quantity displays seasonality, $85 \%$ of supplies remain between 250 and $500 \mathrm{~kg} /$ farmer/week (Figure 3d).
Equitable aggregation schemes 

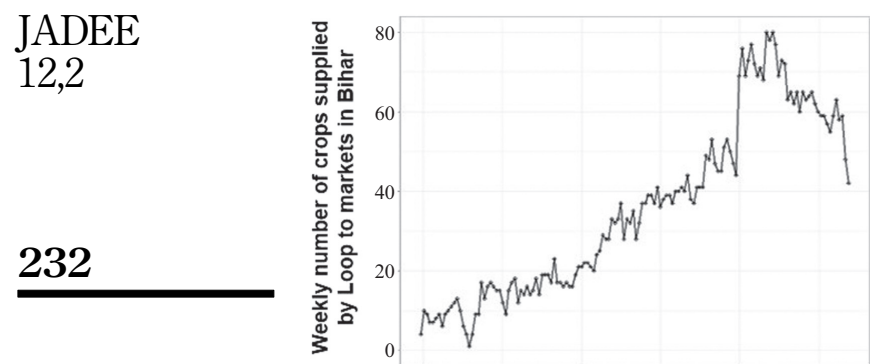

(a)

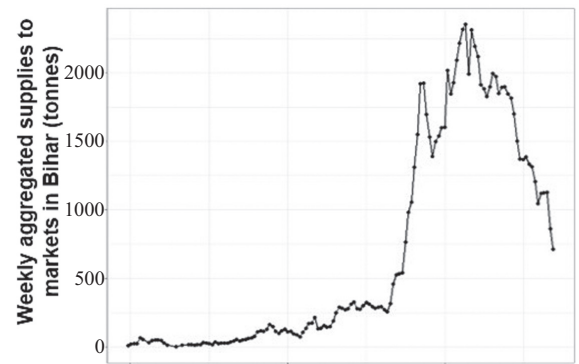

(b)

Figure 3.

Time series tracking the evolution of six Loop outcomes from January 2016 to September 2018; (a) number of products supplied by Loop; (b) quantity of market supplies; (c) number of markets supplied; (d) mean quantity per farmer sold through Loop; (e) mean weekly per farmer revenue; (f) mean transport costs paid by Loop farmers

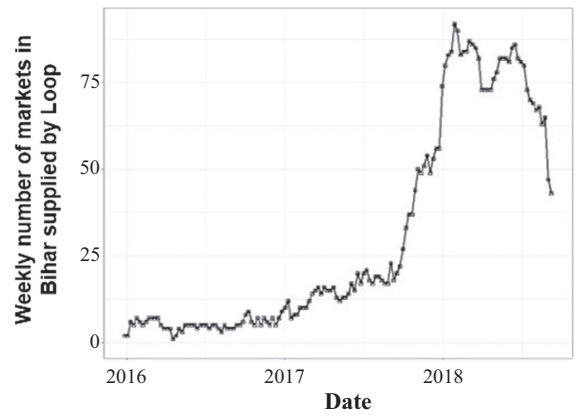

(c)

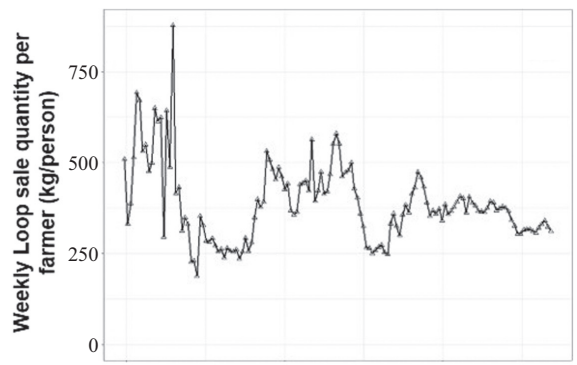

(d)

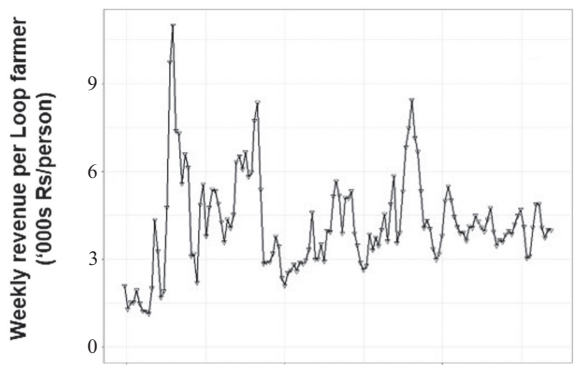

(e)

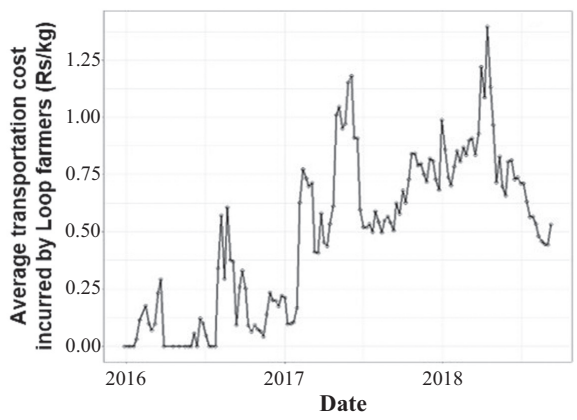

(f)

Source(s): Loop dashboard. The summary statistics underlying the time series are provided in Appendix 2, whilst the seasonal F\&V composition of aggregations is presented in Appendix 3

In turn, the average revenue equalled 4,200 Rs/farmer/week (average of 2.5 supplies per week), with revenues peaking during the onset of the monsoon season as F\&V supplies begin to wane (Figure 3e). The average cost incurred by farmers to transport Loop supplies to market was 0.50 $\mathrm{Rs} / \mathrm{kg} /$ farmer between January 2016 and September 2018 (including subsidies), whilst the oftquoted figure for non-Loop transport in Buxar, Nalanda and Muzaffarpur districts ranges between 1.5 and $2.0 \mathrm{Rs} / \mathrm{kg}$. However, Loop transport has become more expensive for farmers over time (Figure 3f) due to the retraction of subsidies provided by Digital Green, which averaged $72 \%$ of the transport cost in 2016 , but $34 \%$ of the transport cost for the first 9 months of 2018 [2]. 


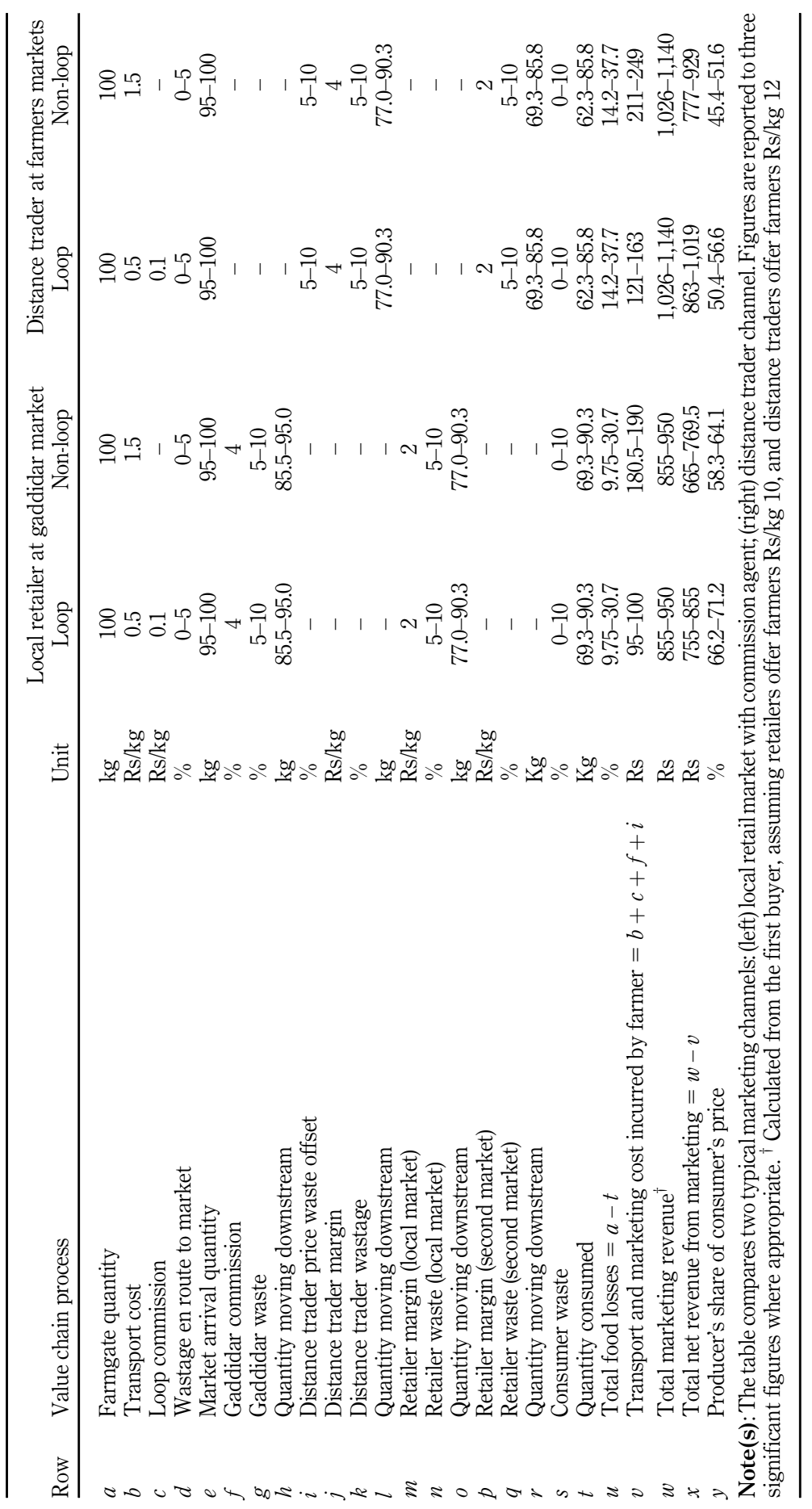

Equitable aggregation schemes

233

Table 2.

Breakdown of the value additions, costs and loss rates effecting

Loop and non-Loop farmers at various stages of the F\&V value chain in Bihar 
JADEE 12,2

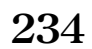

This difference in per unit transport costs underpins the estimated 9.5-13.5\% increase in marketing net returns for Loop farmers relative to non-Loop farmers (Table 2), although the exact benefit on any given day varies as a function of prices, commission rates and loss rates. For instance, the interviewed traders estimated that loss rates may reach $10 \%$ for highly perishable items such as chillies, okra and spinach, but remain $5 \%$ or less for vegetables that are traditionally transported in crates, such as onion and tomato. Therefore, whilst traditionally varying between 5 and $10 \%$ of the transaction's value (Table 2), the wastage levies that traders charge farmers to offset the risks of losses occurring downstream depend on the product being traded and expectations around road, traffic and weather conditions.

In addition, interviewed farmers explained how removing the need to visit the market has provided time savings between 30 min for farmers living close to a market and $10 \mathrm{~h}$ for farmers needing to travel and sit at a market until a buyer is found. Farmer 4 in Buxar district noted that "the convenience [of Loop] has freed up the rest of my morning", with farmers now investing the spare time into recreation, as well as on-farm, domestic and secondary revenue generating activities.

It can be argued that Loop has built foundations to improve $\mathrm{F} \& \mathrm{~V}$ availability and affordability in local markets by stimulating: (1) lower marketing costs relative to non-Loop pathways, (2) an increasingly diverse product base and (3) supplies to an increasing number of markets. However, whether these producer-facing successes can improve F\&V availability in local markets remains an open question.

4.2.2 Clustering of aggregation pathways. The spatial footprint of Loop represents a network of village to market supply pathways. Decisions regarding which market to supply are made jointly by farmers and aggregators, with the aggregators interviewed stressing the importance of expected prices, transport costs and the assurance that all of the aggregation will be sold.

The evolution of Loop over space largely reflects these decision-making processes. During Loop's expansion in 2017, 40\% of supplies were sold to the large hub markets in Samastipur and Bihar Sharif, which attract distance traders exporting in bulk to markets in the neighbouring states of Uttar Pradesh, Jharkhand and West Bengal. Consequently, hub markets in Bihar tend to be the largest in terms of physical size and the volumes of produce handled (i.e. $>100$ tonnes/day), as well as the most infrastructurally developed (i.e. surfaced roads, electricity and storage).

The clustering of supply pathways is observable at the district level. Of the 33 villages mapped in Bhojpur district, 24 have supplied Arra wholesale market (the district capital) and 17 villages have supplied the neighbouring wholesale market in Kayamnagar (Figure 4a). Aggregations can be seen to directly bypass smaller markets; for example, the village of Chakia has transported $90 \%$ of its Loop supply to Arra (40 km to the north) and only $10 \%$ of supplies to Garahani (less than half the distance to Arra). The average aggregation quantities from Chakia to Arra and Garahani equal 1,800 kg and 1,200 kg, respectively, which translate into transport costs of $0.49 \mathrm{Rs} / \mathrm{kg}$ for Arra $(n=84)$ and 1.77 $\mathrm{Rs} / \mathrm{kg}$ for Garahani $(n=15)$.

Differences in transport costs further encourage supplies to higher-demand, highercapacity markets. Trader 2 (Muzaffarpur district) estimated that " $80 \%$ of Loop supplies to Ganj Bazar [wholesale market] are bought by distance traders". This dynamic may reinforce intra-market governance structures and is intrinsic to the preference for urban hub markets, with convenience and guaranteed sales a priority for farmers and aggregators. Moreover, through motorised four-wheeler provision, Loop farmers stated that they no longer rely on short-range, low-capacity motorbikes and bicycles. This raises additional potential challenges for equitable $\mathrm{F} \& \mathrm{~V}$ delivery, as an aggregation of $1,500 \mathrm{~kg}$ is unlikely to fetch a profitable price at a rural market with a capacity of $4,000-5,000 \mathrm{~kg} / \mathrm{day}$. 


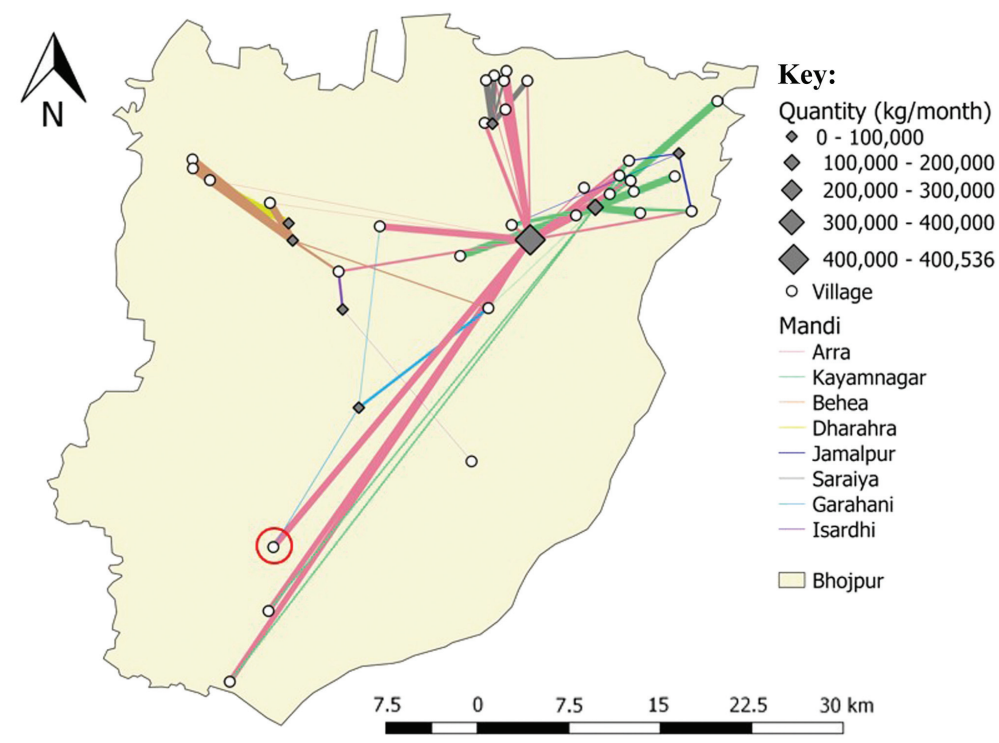
schemes

\section{Supply proportion (\%) 100}

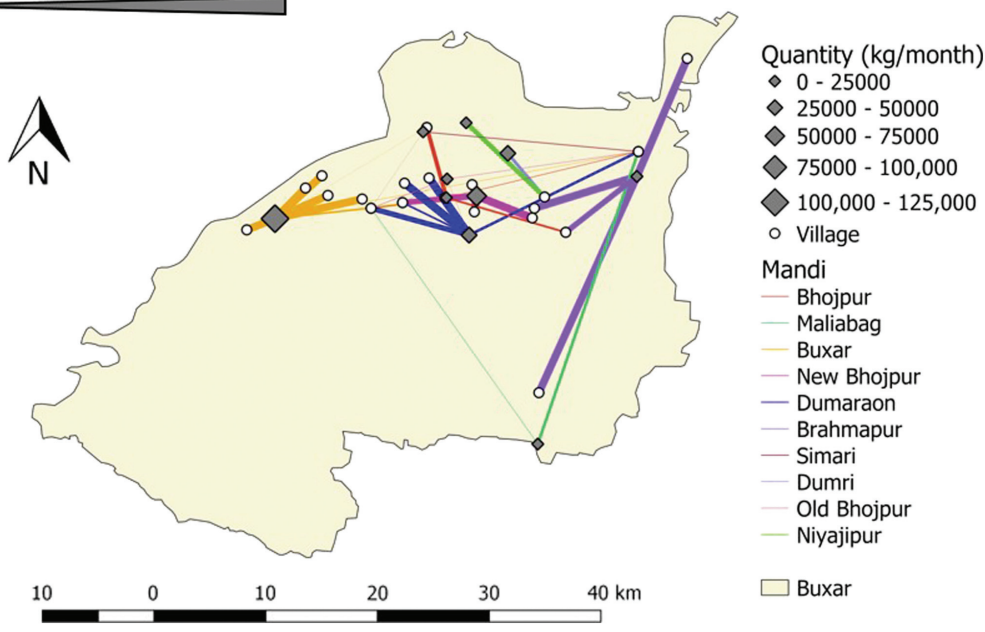

Source(s): Loop dashboard. Summary statistics underlying the village to market pathways are provided in Appendix 2

Figure 4.

Aggregation supply pathways connecting villages to markets in

(a) Bhojpur and (b)

Buxar districts. The thickness of each line is proportional to the percentage of each village's Loop supply that flows along the pathway. Note the different market quantity scales between Bhojpur and Buxar districts. Chakia village is ringed in red 
JADEE

12,2

236

\section{Discussion}

This study has identified actors, interlinkages and decision-making processes that drive F\&V supplies across the horticultural value chain of Bihar. Numerous challenges exist between the producer-driven outcomes of aggregation schemes and the wider desires to improve F\&V availability in access-vulnerable markets. Therefore, successfully utilising improved producer mobility, lower transport costs and coordinated supplies to improve equitable F\&V delivery must overcome various social, infrastructural and financial barriers, including an enabling environment oriented towards the financial demands of upstream actors. Here we discuss plausible scenarios and pathways to overcome the identified barriers and trade-offs, before evaluating our methodological approach.

\subsection{Internal scenarios of change}

Given that day-to-day participation in aggregation is voluntary, changes to aggregation supply pathways must consider potential feedbacks on market access, costs and revenues. For example, if Loop remains relatively profitable, the numbers of aggregating farmers may continue to increase and/or farmers may aggregate more frequently. Yet, based on the aggregation scheme's evolution to date, doing nothing may strengthen the flows of F\&V to urban hubs, with potentially limited benefits for relatively isolated local markets.

Therefore, how may aggregation schemes equitably guide $F \& V$ supplies towards smaller markets? Whilst at present one vehicle aggregates the available supply from each cluster, multiple vehicles could potentially supply different markets - although this strategy could potentially undermine farmers' uniform market access. To counter this, different rates of subsidy could be introduced to reduce transport costs to smaller markets. Similar to the pricing models of app-based taxis, subsidy rates could be linked to Loop supplies and/or market demands. For example, regarding Chakia village (Section 4.2.2), Loop would have to subsidise the current cost of supplying Garahani market by $77 \%$ to align with the cost of supplying Arra. However, such an approach could quickly become complex, as subsidy rates would need to be tailored to individual supply pathways that potentially vary day by day.

Given the retail price differences between high- and low-quality $\mathrm{F} \& \mathrm{~V}$ can reach $50 \%$, aggregation could distribute lower-grade produce towards supply-limited markets in an attempt to increase the availability of relatively cheap supplies. However, aggregators are not traditionally involved in the F\&V grading, meaning such tasks could increase the cost of aggregation participation. Moreover, differentiating market destinations by F\&V quality may lead to divergent outcomes between farmers supplying different grades - potentially leading to an inequitable "success to the successful" type scenario. Lastly, with perceptions of food quality playing an increasingly important role in consumption decisions (Minten et al., 2013; Patil et al., 2016), there is no guarantee that lower-grade produce would be purchased even in access-limited areas of Bihar. The adaptability of aggregation supply pathways may also be constrained by trust-based relationships between Loop and wider value chain actors. Consistent with the findings of Minten et al. (2010) for horticultural wholesale markets in Uttarkhand state, and Vandeplas et al. (2013) for the dairy value chain of Punjab state, we find that trust continues to inform market choices even when alternative marketing channels are available and promoted - as in the case of Bihar, where APMC regulations were repealed in 2006. Therefore, efforts to adapt aggregation pathways must first escape the economic and trust-based pull of the larger market, before establishing new relationships with commission agents and traders in alternative markets. Even then, there is no guarantee that the end consumer will change, as local traders in smaller markets may then supply larger regional hubs. Therefore, the quantities, qualities and types of product supplied to smaller markets would have to be carefully tailored to local demands to avoid crashing prices, increasing wastage and degrading the long-term willingness of farmers/aggregators to supply rural markets. 


\subsection{Scenarios for the wider enabling environment}

There is increasing recognition that improving the availability of $\mathrm{F} \& \mathrm{~V}$ in developing contexts is as much about distribution as it is production (Gupte and Longhurst, 2019). Therefore, to simultaneously cut transportation costs whilst working towards consumerfocussed goals, aggregation schemes in developing contexts such as north India need to be supported by improvements in road connectivity, cold chains and market infrastructure, which tend to be the responsibilities of district and/or state governments.

For instance, evidence from the potato value chain in Bihar suggests that cold storage can dampen short-term price variations (Minten et al., 2011). Despite the number of cold storage facilities increasing by $67 \%$ from 2000 to 2010 , the latest data suggests that Bihar still has the third widest horticultural cold storage deficit of all Indian states (Vanitha et al., 2013). Yet, combined with reduced wastage rates, $\mathrm{F} \& \mathrm{~V}$ storage may allow producers and traders to better align supply with demand and better connect supplies to rural markets. Such a strategy would require significant state investment to build new facilities (Narula, 2011) or a weakening of the cold storage monopoly held by potato traders in Bihar (Minten et al., 2011). Moreover, traders in Bihar Sharif market (Nalanda district) described how particular F\&V products would be moved into storage prior to festivals in order to artificially inflate prices. Therefore, the expansion of cold storage in Bihar has to be carefully monitored to provide equitable benefits for actors across the value chain.

Even if cold storage facilities are to be located geographically close to rural markets, poor road qualities can produce "economic distances" that make supplying local markets unattractive (Reardon, 2015). Although the length of roads in Bihar doubled between 2009 and 2018, only half of roads in and out of villages are paved (GoB, 2019). Consequently, rural roads may be impassable for farmers dependent on bicycles or autorickshaws, whilst traders and aggregators may have to take costly precautions to avoid damaging supplies (i.e. additional packaging or longer routes).

Improving the connectivity of rural markets is counterproductive if any increase in supplies will overwhelm market infrastructure and consumer demand. One approach to counter this would be to increase the density of rural markets, with inter-market competition promoting the diversity and quality of F\&V (Chatterjee and Kapur, 2017). However, whilst more markets might reduce economic distances for rural consumers, their limited capacities are unlikely to attract bulky aggregations. Therefore, increasing the size of existing rural markets may better accommodate aggregations whilst benefiting from economies of scale to control infrastructure costs (e.g. space and electricity).

These external scenarios are ultimately interdependent: for instance, increases in rural market capacities must be coupled with adequate transport and storage facilities to connect farmers, traders and consumers to market. The different time scales must also be acknowledged; whilst aggregations schemes may change their supply destinations daily, changes to the enabling environment may follow government budget cycles. Therefore, the consumer sensitivity of aggregation schemes in developing contexts may be constrained until changes to the wider enabling environment unlock their nutritional potential.

\subsection{Evaluating our VCA approach}

The VCA conducted here integrates stakeholder interviews with spatiotemporal transaction data to identify challenges of aligning aggregation with equitable F\&V delivery. Whilst the integration of qualitative and quantitative data is not novel in itself (see Minten et al., 2013; Reardon et al., 2012), our approach makes three contributions to the need to make agricultural value chains (and their assessments) work for all (Gelli et al., 2015; Hawkes and Ruel, 2011).

First, this analysis emphasises the importance of assessing specific interventions within the wider context of the host value chain. Whilst traditional firm-level analysis may be appropriate where products are procured, developed and marketed with limited external
Equitable aggregation schemes

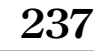


JADEE 12,2

\section{8}

interference, more holistic approaches are required to capture the feedbacks, delays and conflicts of interest that drive horticultural products downstream and the flows of information and financial returns upstream. The traditional prioritisation of upstream segments may have stopped short of analysing the downstream factors that modify the potential for aggregation to align with consumer-facing goals, including the preference of consumers to visit markets with a diverse choice of local produce and the tendency of traders to reinforce underlying access vulnerabilities by inflating retail prices.

Second is the growing need to explore who benefits from value chain upgrades (Maestre and Poole, 2018; Vicol et al., 2018). The integration of qualitative and quantitative information here was key to identifying governance structures and trust-based relationships that underpin the urban-centric supply pathways. Conversely, aligning aggregation with the needs of access-vulnerable consumers risks weakening these relationships and trading-off traditional value chain outcomes, such as market participation, revenues and efficiencies. Therefore, establishing the feedbacks, interlinkages and governance structures across the holistic value chain is key to identifying the synergies that work towards elusive win-win futures (Klapwijk et al., 2014).

Third, this study supports the continued evolution of VCA approaches, from taking snapshots at one point in time, to integrated approaches that capture the spatiotemporal complexity of food systems. Given that food systems in developing countries are rapidly lengthening and urbanising (Reardon et al., 2019; Reardon and Minten, 2011), the ability to identify value chain complexities is a precondition to designing upgrades and policies that appreciate the nonlinear nature of cause-effect pathways, unintended consequences and trade-offs (Routroy and Behera, 2017).

This analysis is not without limitations. Despite capturing the roles and interlinkages of actors, our VCA does not offer the same level of detail or statistical power as more specialist techniques (e.g. dietary diversity surveys), particularly with regard to consumer preferences and habits. In relation, whilst broadly consistent with the loss rates reported elsewhere for Bihar (Kumari et al., 2017; World Bank, 2007) and India (Minocha et al., 2018; Parfitt et al., 2010), it is important to acknowledge that the food loss rates and trader margins reported here derive from a small number of surveys that are primarily qualitative in nature. Moreover, the traditional method to estimate $\mathrm{F} \& \mathrm{~V}$ losses by mass may overestimate the contribution of heavier, "low-value products" (FAO, 2019, p. xiii). Therefore, future value chain studies may look to incorporate the economic values and/or nutritional importance of horticultural products (e.g. the loss of micronutrients or protein availability) to better understand the socioeconomic and health implications of food losses (FAO, 2019; Ritchie et al., 2018).

Finally, with the Loop dashboard lacking data on the quality of F\&V sold through aggregation, as well as data from before the intervention started, the diversion of $\mathrm{F} \& \mathrm{~V}$ quantities and qualities away from local markets has not been quantified. In spite of this, the resolution and range of data available within the Loop dashboard are unparalleled for this region. The incorporation of near real-time data into technology-based interventions is strongly encouraged to allow time-sensitive value chain evaluations in future.

\section{Conclusions: lessons for access-sensitive aggregation schemes}

Through an assessment of the Loop aggregation scheme in Bihar, this paper has explored the potential challenges of using aggregation to improve $F \& V$ availability in access-vulnerable markets. As a launchpad for further enquiry, we summarise four key conclusions to be considered when aligning aggregation with consumer-focussed goals, such as food prices and availability.

First, Loop-type aggregation schemes provide economic and social benefits for producers. Loop has cut transport costs by at least half relative to non-Loop supply pathways, and 
access to motor vehicles has empowered farmers to supply more distant, higher-demand markets. Moreover, Loop may save farmers up to $10 \mathrm{~h}$ per market day by removing the need to visit the market. Such convenience may be particularly beneficial for farmers with mobility limitations (i.e. elderly farmers) and/or domestic responsibilities (i.e. female farmers).

However, secondly, these producer-facing outcomes may not immediately translate into widespread consumer-focussed benefits. Although the promotion of horticulture through Loop may increase F\&V availability at the farm household level, aggregated volumes are often too bulky to be absorbed by local markets. In association, we observe the clustering of aggregation pathways around regional hubs, including instances of pathways directly bypassing smaller markets. However, with a view to future research, we cannot currently assess the extent to which the clustering of village to market pathways (1) is directly caused by aggregation or (2) has significantly influenced the affordability of $\mathrm{F} \& \mathrm{~V}$ in bypassed local markets. Therefore, the observed spatiotemporal patterns better represent a baseline of barriers that resist aggregation schemes achieving more equitable distribution.

Thirdly, aggregation pathways are also constrained by various value chain characteristics. Despite operating in an unregulated, traditional market system, commission agents remain important sources of agricultural, informational and financial inputs. Long-standing trustbased relationships can be hard to break and build, particularly if the F\&V supply does not conform to local demands. Additional layers of informal governance, such as the tendency of local traders to inflate prices for retail transactions and the dominance of distance traders in regional hubs, further suppress F\&V accessibility in local markets.

Finally, aggregation schemes such as Loop require support from the broader enabling environment, particularly government policy, to leverage widespread nutritional benefits. For example, introducing subsidies to equitably offset the extra costs of supplying rural markets might encourage farmers to divert $\mathrm{F} \& \mathrm{~V}$ away from larger markets in the short term. However, the strategy may become socioeconomically unsustainable for actors across the value chain without any stimulation of demand, such as upgraded transport infrastructure to improve consumer accessibility and/or the growth of cold chains to stabilise prices. Therefore, wider enabling environments may themselves have to be upgraded before the full consumer-facing potential of aggregation can be unlocked.

\section{Notes}

1. One Indian rupee (Rs 1$)=0.014$ US dollars (25th November 2020).

2. Loop has undergone rapid changes since late-2018 as it moves towards a subscription-based model. This paper assesses the traditional aggregation model (Section 2) as it is most generalisable and covers the period of quantitative data (January 2016-September 2018).

\section{References}

Anjalay, B. and Bhamoriya, V. (2011), "Samriddhii: redesigning the vegetable supply chain in Bihar", Indore Management Journal, Vol. 2, pp. 40-52.

Aune, D., Giovannucci, E., Boffetta, P., Fadnes, L., Keum, N., Norat, T., Greenwood, D., Riboli, E., Vatten, L. and Tonstad, S. (2017), "Fruit and vegetable intake and the risk of cardiovascular disease, total cancer and all-cause mortality - a systematic review and dose-response metaanalysis of prospective studies", International Journal of Epidemiology, Vol. 46, pp. 1029-1056, doi: 10.1093/ije/dyw319.

Chatterjee, S. and Kapur, D. (2017), "Six puzzles in Indian agriculture", The Indian Policy Forum 2016201743.

Choudhury, S., Shankar, B., Aleksandrowicz, L., Tak, M., Green, R., Harris, F., Scheelbeek, P. and Dangour, A. (2020), "What underlies inadequate and unequal fruit and vegetable consumption 
JADEE 12,2

240

in India? An exploratory analysis", Global Food Security, Vol. 24, p. 100332, doi: 10.1016/j.gfs. 2019.100332.

Devaux, A., Torero, M., Donovan, J. and Horton, D. (2018), "Agricultural innovation and inclusive value-chain development: a review", Journal of Agribusiness in Developing and Emerging Economies, Vol. 8, pp. 99-123, doi: 10.1108/JADEE-06-2017-0065.

Digital Green (2017), Digital Green's LOOP: Pooling Technology and Extension Networks for Market Access, New Delhi.

FAO (2014), Global Initiative on Food Loss and Waste Reduction, Rome.

FAO (2019), The State of Food and Agriculture: Moving Forward on Food Loss and Waste Reduction, Rome.

Fischer, E. and Qaim, M. (2012), "Linking smallholders to markets: determinants and impacts of farmer collective action in Kenya”, World Development, Vol. 40, pp. 1255-1268, doi: 10.1016/j. worlddev.2011.11.018.

Gelli, A., Hawkes, C., Donovan, J., Harris, J., Allen, S., de Brauw, A., Henson, S., Johnson, N., Garrett, J. and Ryckembusch, D. (2015), "Value chains and nutrition: a framework to support the identification, design, and evaluation of interventions", available at: https://a4nh.cgiar.org/files/ 2012/07/Value_chains_and_nutrition_A_framework_to_support_the_identification_design_ and_evaluation_of_interventions.pdf.

Gereffi, G., Humphrey, J. and Sturgeon, T. (2005), “The governance of global value chains”, Review of International Political Economy, Vol. 12, pp. 78-104, doi: 10.1080/09692290500049805.

GoB (2019), Bihar Economic Survey: 2018-2019, Patna.

Govil, R., Rana, G. and Dixit, S. (2014), Creating a Rural-To-Rural Vegetable Supply Chain, Mumbai.

Gupte, J. and Longhurst, R. (2019), "How do the state's organisational capacities at the micro- and macro-levels influence agriculture-nutrition linkages in fragile contexts?", Food Policy, Vol. 82, pp. 74-83, doi: 10.1016/j.foodpol.2018.10.016.

Hainzer, K., Best, T. and Brown, H.P. (2019), "Local value chain interventions: a systematic review", Journal of Agribusiness in Developing and Emerging Economies, Vol. 9, pp. 369-390, doi: 10.1108/ JADEE-11-2018-0153.

Halder, P. and Pati, S. (2011), "A need for paradigm shift to improve supply chain management of fruits and vegetables in India", Asian Journal of Agriculture and Rural Development, Vol. 1 No. 3, p. 20, available at: https://doi.org/ISSN(P): 2304-1455.

Hawkes, C. and Ruel, M.T. (2008), "From agriculture to nutrition: pathways, synergies and outcomes", Agricultural and Rural Development Notes, Vol. 40, p. 4.

Hawkes, C. and Ruel, M.T. (2011), "Value chains for nutrition", IFPRI 2020 International Conference "Leveraging Agriculture for Improving Nutrition and Health, New Delhi, p. 4.

Kaplinsky, R. and Morris, M. (2001), A Handbook for Value Chain Research.

Klapwijk, C.J., van Wijk, M.T., Rosenstock, T.S., van Asten, P.J.A., Thornton, P.K. and Giller, K.E. (2014), "Analysis of trade-offs in agricultural systems: current status and way forward", Current Opinion in Environmental Sustainability, Vol. 6, pp. 110-115, doi: 10.1016/j.cosust.2013.11.012.

Kubzansky, M., Cooper, A. and Barbary, V. (2011), Promise and Progress: Market-Based Solutions to Poverty in Africa, Cambridge, Massachesetts.

Kumari, M., Bairwa, S.L., Meena, L. and Rahman, S.M. (2017), “Availability and post-harvest losses of fruits and vegetable in Bihar: economic analysis", International Journal of Agricultural Invention, Vol. 1, pp. 207-212.

Kumari, M., Singh, R. and Kumar, R. (2020), "Issues and approaches for linking small vegetables growers to markets in Bihar: a policy brief", Journal of Pharmacognosy and Phytochemistry, Vol. 9, pp. 418-423. 
Maestre, M. and Poole, N. (2018), "Introduction: value chains for nutrition in South Asia: who delivers, how, and to whom?", in Value Chains for Nutrition in South Asia: Who Delivers, How, and to Whom? Institute of Development Studies Bulletin, Brighton, Vol. 49, No. 1, pp. 1-20.

Maestre, M., Poole, N. and Henson, S. (2017), "Assessing food value chain pathways, linkages and impacts for better nutrition of vulnerable groups”, Food Policy, Vol. 68, pp. 31-39, doi: 10.1016/j. foodpol.2016.12.007.

Minocha, S., Thomas, T. and Kurpad, A.V. (2018), “Are 'fruits and vegetables' intake really what they seem in India?”, European Journal of Clinical Nutrition, Vol. 72, pp. 603-608, doi: 10.1038/s41430018-0094-1.

Minten, B., Vandeplas, A., Ghorpade, Y. and Swinnen, J.F.M. (2010), "Horticulture wholesale trade and governance in India: evidence from Uttarakhand", Journal of South Asian Development, Vol. 5, pp. 113-136, doi: 10.1177/097317411000500105.

Minten, B., Reardon, T., Singh, K.M. and Sutradhar, R. (2011), The Potato Value Chain in Bihar: An Assessment and Policy Implications.

Minten, B., Singh, K.M. and Sutradhar, R. (2013), "Branding and agricultural value chains in developing countries: insights from Bihar (India)”, Food Policy, Vol. 38, pp. 23-34, doi: 10.1016/j. foodpol.2012.09.003.

Narula, S.A. (2011), "Reinventing cold chain industry in India: need of the hour. Interview with $\mathrm{Mr}$ Sanjay Aggarwal”, Journal of Agribusiness in Developing and Emerging Economies, Vol. 1, doi: 10.1108/jadee.2011.52401baa.001.

NSSO (2013), Household Consumer Expenditure, NSS 68th Round Sch1.0 Type 1, July 2011-June 2012, New Delhi.

Orr, A. and Donovan, J. (2018), "Introduction to special issue: smallholder value chains as complex adaptive systems", Journal of Agribusiness in Developing and Emerging Economies, Vol. 8, pp. 2-13, doi: 10.1108/JADEE-11-2017-0123.

Parfitt, J., Barthel, M. and Macnaughton, S. (2010), "Food waste within food supply chains: quantification and potential for change to 2050", Philosophical Transactions of the Royal Society B: Biological Sciences, Vol. 365, p. 3065.

Patil, S., Jha, A.K. and Sinha, A. (2016), "Role of financial agencies in integrating small farmers into a sustainable value chain: a synthesis-based on successful value chain financing efforts", Current Science, Vol. 110, pp. 2082-2090, doi: 10.18520/cs/v110/111/2082-2090.

R (2013), R: A Language and Environment for Statistical Computing, Vienna.

Rahman, A. (2012), Characterizing Food Prices in India, Mumbai.

Reardon, T. (2015), "The hidden middle: the quiet revolution in the midstream of agrifood value chains in developing countries", Oxford Review of Economic Policy, Vol. 31, pp. 45-63, doi: 10.1093/ oxrep/grv011.

Reardon, T. and Minten, B. (2011), "Surprised by supermarkets: diffusion of modern food retail in India”, Journal of Agribusiness in Developing and Emerging Economies, Vol. 1, pp. 134-161, doi: $10.1108 / 20440831111167155$.

Reardon, T., Chen, K.Z., Minten, B. and Adriano, L. (2012), The Quiet Revolution in Staple Food Value Chains: Enter the Dragon, the Elephant, and the Tiger, Asian Development Bank and International Food Poilucy Research Institute, Mandaluyong City, available at: http://ebrary. ifpri.org/utils/getfile/collection/p15738coll2/id/127312/filename/127523.pdf.

Reardon, T., Echeverria, R., Berdegué, J., Minten, B., Liverpool-Tasie, S., Tschirley, D. and Zilberman, D. (2019), "Rapid transformation of food systems in developing regions: highlighting the role of agricultural research and innovations", Agricultural Systems, Vol. 172, pp. 47-59, doi: 10.1016/j. agsy.2018.01.022.

Ritchie, H., Reay, D.S. and Higgins, P. (2018), "Beyond calories: a holistic assessment of the global food system", Frontiers in Sustainable Food Systems, Vol. 2, p. 57, doi: 10.3389/fsufs. 2018.00057. 
JADEE 12,2

\section{2}

Table A1.

Overview of the range of discussion topics included in the semistructured interviews with participants from across the horticultural value chain of Bihar, India
Routroy, S. and Behera, A. (2017), "Agriculture supply chain: a systematic review of literature and implications for future research", Journal of Agribusiness in Developing and Emerging Economies, Vol. 7, pp. 275-302, doi: 10.1108/JADEE-06-2016-0039.

Shepherd, A.W. (2018), Addressing the Aggregation and Coordination Problems in Smallholder-Based Value Chains, Washington, DC.

Sinha, I.B. and Kumar, R.S. (2015), "Development challenges of exclusion and strategies for inclusive growth in Bihar: the gender perspective", Indian Anthropologist, Vol. 45, pp. 25-42.

UN (2015), Transforming Our World: The 2030 Agenda for Sustainable Development.

Vandeplas, A., Minten, B. and Swinnen, J. (2013), "Multinationals vs. cooperatives: the income and efficiency effects of supply chain governance in India", Journal of Agricultural Economics, Vol. 64, pp. 217-244, doi: 10.1111/1477-9552.12004.

Vanitha, S.M., Chaurasia, S.N.S., Singh, P.M. and Naik, P.S. (2013), Vegetable Statistics - Technical Bulletin, Varanasi.

Vicol, M., Neilson, J., Hartatri, D.F.S. and Cooper, P. (2018), "Upgrading for whom? Relationship coffee, value chain interventions and rural development in Indonesia", World Development, Vol. 110, pp. 26-37, doi: 10.1016/j.worlddev.2018.05.020.

Wiggins, S. and Compton, J. (2016), Factors Leading to Agricultural Production Aggregation and Facilitation of the Linkage of Farmers to Remunerative Markets.

World Bank (2007), Bihar Agriculture: Building on Emerging Models of "Success", Washington, DC.

World Bank (2016), Bihar: Poverty, Growth and Inequality, Washington, DC.

World Bank (2018), Case Study: Private Sector Supply Chain, Development for Launch of New Ugandan Beer, Washington, DC.

Appendix 1

Overview of interview discussion topics

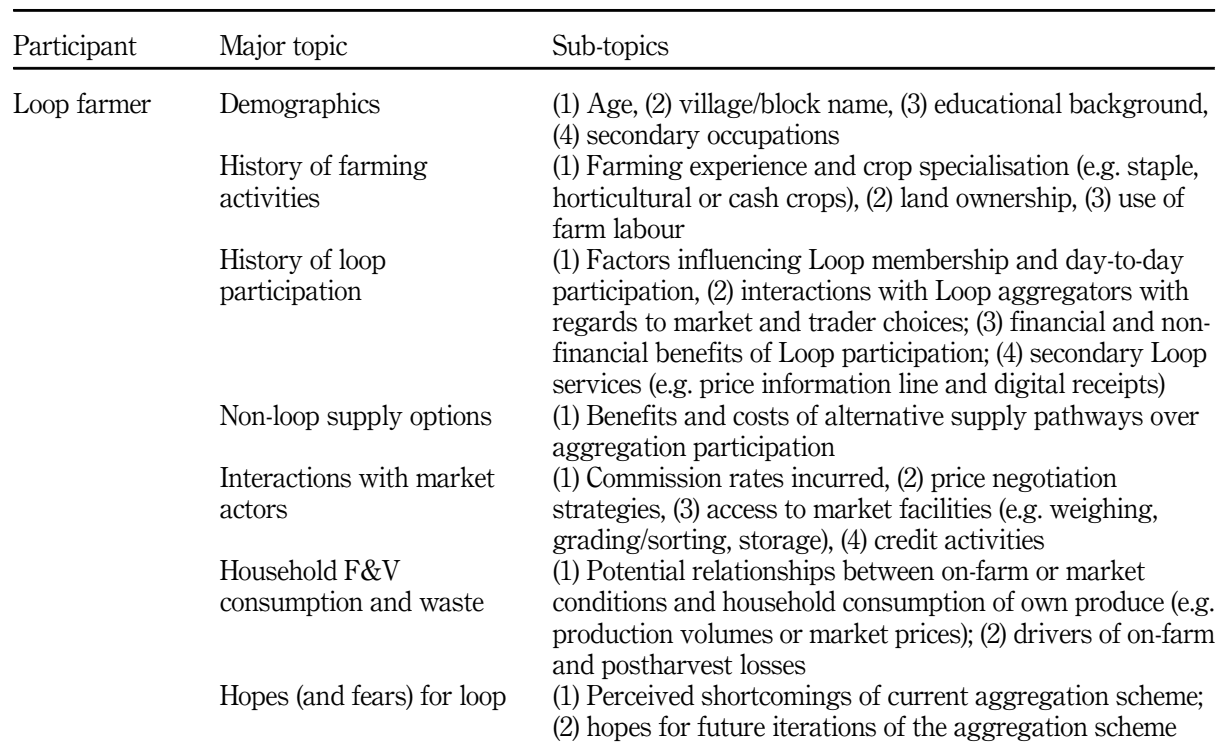

(continued) 


\begin{tabular}{|c|c|c|c|}
\hline Participant & Major topic & Sub-topics & Equitable \\
\hline \multirow[t]{5}{*}{ Aggregator } & Demographics & $\begin{array}{l}\text { (1) Age, (2) village/block name, (3) educational background, } \\
\text { (4) secondary occupations }\end{array}$ & schemes \\
\hline & Role in aggregation & $\begin{array}{l}\text { (1) Vehicle ownership, (2) weekly and seasonal aggregation } \\
\text { schedules, (3) transport costs and commission, (4) } \\
\text { interactions with Loop aggregators with regards to market } \\
\text { and trader choices, (5) drivers and safeguards against food }\end{array}$ & 243 \\
\hline & $\begin{array}{l}\text { Interactions with market } \\
\text { actors }\end{array}$ & $\begin{array}{l}\text { loss } \\
\text { (1) Commission incurred, (2) price information, (3) access to } \\
\text { market facilities (e.g. weighing, grading/sorting, storage), (4) } \\
\text { external influences (e.g. transport infrastructure) on market } \\
\text { choice }\end{array}$ & \\
\hline & Loop services & $\begin{array}{l}\text { (1) Loop smartphone app, (2) digital receipts, (3) market price } \\
\text { hotline }\end{array}$ & \\
\hline & Hopes (and fears) for loop & $\begin{array}{l}\text { (1) Perceived shortcomings of aggregation scheme; (2) hopes } \\
\text { for future iterations of the scheme }\end{array}$ & \\
\hline \multirow[t]{4}{*}{$\begin{array}{l}\text { Commission } \\
\text { agent }\end{array}$} & Demographics & $\begin{array}{l}\text { (1) Age, (2) village/block name, (3) educational background, } \\
\text { (4) secondary occupations }\end{array}$ & \\
\hline & $\begin{array}{l}\text { Overview of commission } \\
\text { activities }\end{array}$ & $\begin{array}{l}\text { (1) Daily capacities and costs, (2) crop specialisation, (3) } \\
\text { Commissions charged, (4) value chain structure (i.e. "inside" } \\
\text { and "outside" gaddidars), (5) seasonality of above }\end{array}$ & \\
\hline & $\begin{array}{l}\text { Interactions with other } \\
\text { market actors }\end{array}$ & $\begin{array}{l}\text { (1) Seasonality of selling farmers and procuring traders (1) } \\
\text { Access to market facilities and services provided (e.g. credit } \\
\text { provision, weighing, grading/sorting, storage) }\end{array}$ & \\
\hline & Barriers to trade & $\begin{array}{l}\text { (1) Determinants of food loss, (2) Government regulations, (3) } \\
\text { other perceived issues }\end{array}$ & \\
\hline \multirow[t]{6}{*}{ Wholesaler } & Demographics & $\begin{array}{l}\text { (1) Age, (2) village/block name, (3) educational background, } \\
\text { (4) secondary occupations }\end{array}$ & \\
\hline & $\begin{array}{l}\text { Overview of trading } \\
\text { activities }\end{array}$ & $\begin{array}{l}\text { (1) Vehicle ownership, (2) daily capacities and costs, (3) crop } \\
\text { specialisation, (4) buying and selling market locations, (5) } \\
\text { seasonality of above }\end{array}$ & \\
\hline & $\begin{array}{l}\text { Determinants of market } \\
\text { supplies }\end{array}$ & $\begin{array}{l}\text { (1) Decision-making process determining where to buy and } \\
\text { sell produce (e.g. expected profits, travel times, relationships } \\
\text { with market actors); (2) changes in volumes traded over last } \\
2-5 \text { years }\end{array}$ & \\
\hline & $\begin{array}{l}\text { Interactions with other } \\
\text { market actors }\end{array}$ & $\begin{array}{l}\text { (1) Actors upstream and downstream of trader, (2) } \\
\text { commissions incurred, (3) access to market facilities (e.g. } \\
\text { weighing, grading/sorting, storage) }\end{array}$ & \\
\hline & Barriers to trade & $\begin{array}{l}\text { (1) Determinants of food loss, (2) gendered dimensions to } \\
\text { trading, (3) Government regulations, (4) other perceived } \\
\text { issues }\end{array}$ & \\
\hline & & (continued) & Table A1. \\
\hline
\end{tabular}




\section{JADEE 12,2}

\section{4}

\begin{tabular}{|c|c|c|}
\hline Participant & Major topic & Sub-topics \\
\hline \multirow[t]{5}{*}{ Retailer } & Demographics & $\begin{array}{l}\text { (1) Age, (2) village/block name, (3) educational background, } \\
\text { (4) secondary occupations }\end{array}$ \\
\hline & $\begin{array}{l}\text { Overview of retail } \\
\text { activities }\end{array}$ & $\begin{array}{l}\text { (1) Location, number and characteristics of retail customers, } \\
\text { (3) crop specialisation }\end{array}$ \\
\hline & $\begin{array}{l}\text { Interactions with retail } \\
\text { customers }\end{array}$ & $\begin{array}{l}\text { (1) Decision-making processes in price setting, (2) most } \\
\text { popular products by season, (3) attributes prioritised by } \\
\text { consumers when purchasing, (4) perceptions around changes } \\
\text { in demand over last } 2-5 \text { years }\end{array}$ \\
\hline & $\begin{array}{l}\text { Interactions with other } \\
\text { market actors }\end{array}$ & $\begin{array}{l}\text { (1) Upstream procurement processes, (2) alternative } \\
\text { downstream selling pathways (i.e. mobile retailers), (3) } \\
\text { commissions, (4) access to market facilities (e.g. weighing, } \\
\text { grading/sorting, storage) }\end{array}$ \\
\hline & Food safety concerns & $\begin{array}{l}\text { (1) Determinants of food losses, (2) conversations with } \\
\text { customers around nutrition and/or food safety, (3) Any } \\
\text { relevant government regulations around food safety }\end{array}$ \\
\hline \multirow[t]{4}{*}{ Consumer } & Demographics & $\begin{array}{l}\text { (1) Age, (2) village/block name, (3) educational background, } \\
\text { (4) occupations, (5) household size }\end{array}$ \\
\hline & Purchasing routines & $\begin{array}{l}\text { (1) Types, frequency and quantities purchases (including } \\
\text { seasonal), (2) household expenditure on fruits and } \\
\text { vegetables, (3) changes in household consumption over past } \\
2-5 \text { years }\end{array}$ \\
\hline & $\begin{array}{l}\text { Interaction with market } \\
\text { actors }\end{array}$ & $\begin{array}{l}\text { (1) Household decision-making responsibilities about } \\
\text { purchases, (2) market and retailer choices, (3) produce/ } \\
\text { retailer characteristics influencing purchasing decisions (e.g. } \\
\text { price discovery) }\end{array}$ \\
\hline & Food safety and security & $\begin{array}{l}\text { (1) Adaptation techniques when prices are high, (2) food } \\
\text { waste in household, (3) conversations with retailers } \\
\text { regarding food safety }\end{array}$ \\
\hline
\end{tabular}

\section{Appendix 2 \\ Quantitative data - summary statistics}

Table A2.

Summary statistics for the quantitative Loop dashboard data presented in Figures 3 and 4 of the main manuscript

\begin{tabular}{|c|c|c|c|c|c|c|c|}
\hline Variable & $n$ & Mean & Median & $\begin{array}{l}\text { Std. } \\
\text { dev. }\end{array}$ & Min. & Max. & Figure \\
\hline $\begin{array}{l}\text { Weekly number of crops supplied to } \\
\text { markets in Bihar }\end{array}$ & 142 & 36.0 & 35 & 22.2 & 1 & 81 & Figure $3 \mathrm{a}$ \\
\hline $\begin{array}{l}\text { Weekly volume of supplies to markets in } \\
\text { Bihar (tonnes) }\end{array}$ & 142 & 662 & 264 & 768 & 0.878 & 2,350 & Figure $3 b$ \\
\hline $\begin{array}{l}\text { Weekly number of markets supplied in } \\
\text { Bihar }\end{array}$ & 142 & 30.3 & 15 & 30.6 & 1 & 92 & Figure $3 c$ \\
\hline $\begin{array}{l}\text { Weekly sale quantity per Loop farmer in } \\
\text { Bihar (kg/person) }\end{array}$ & 142 & 386 & 367 & 107 & 189 & 878 & Figure $3 \mathrm{~d}$ \\
\hline $\begin{array}{l}\text { Weekly revenue per Loop farmer in Bihar } \\
\text { (Rs/person) }\end{array}$ & 142 & 4,200 & 3,980 & 1,650 & 1,130 & 11,000 & Figure $3 \mathrm{e}$ \\
\hline $\begin{array}{l}\text { Transport cost per Loop farmer in Bihar } \\
\text { (Rs/kg/week) }\end{array}$ & 138 & 0.500 & 0.539 & 0.344 & 0 & 1.40 & Figure $3 f$ \\
\hline $\begin{array}{l}\text { Number of villages supplying each market } \\
\text { in Bhojpur }\end{array}$ & 74 & 8.22 & 7 & 7.56 & 1 & 24 & Figure 4a \\
\hline
\end{tabular}




\begin{tabular}{|c|c|c|c|c|c|c|c|}
\hline Variable & $n$ & Mean & Median & $\begin{array}{l}\text { Std. } \\
\text { dev. }\end{array}$ & Min. & Max. & Figure \\
\hline $\begin{array}{l}\text { Number of villages suppling each market } \\
\text { in Buxar }\end{array}$ & 46 & 4.60 & 4 & 2.91 & 1 & 10 & Figure $4 \mathrm{~b}$ \\
\hline $\begin{array}{l}\text { Total supply quantity between villages } \\
\text { and markets in Bhojpur (tonnes) }\end{array}$ & 74 & 126 & 53.3 & 194 & 0.185 & 989 & Figure 4a \\
\hline $\begin{array}{l}\text { Total supply quantity between villages } \\
\text { and markets in Buxar (tonnes) }\end{array}$ & 46 & 82.5 & 15.4 & 139 & 0.243 & 635 & Figure $4 b$ \\
\hline
\end{tabular}

Note(s): All data refers to market transactions conducted through the Loop aggregation scheme between January 2016 and September 2018. All values given to three significant figures where appropriate. "Std.dev." standard deviation

Table A2.

\section{Appendix 3}

\section{Composition of seasonal aggregations}

\begin{tabular}{|c|c|c|c|c|c|c|}
\hline Season & Crop & $\begin{array}{c}\text { Average } \\
\text { transactions per } \\
\text { week }\end{array}$ & $\begin{array}{l}\text { Average quantity } \\
\text { (tonnes/week) }\end{array}$ & $\begin{array}{c}\text { Proportion of } \\
\text { seasonal quantity }(\%)\end{array}$ & $\begin{array}{l}\text { Quantity } \\
\text { rank }\end{array}$ & \\
\hline \multirow[t]{11}{*}{ Rabi } & Cauliflower & 1,060 & 208 & 26.7 & 1 & \\
\hline & Eggplant & 677 & 118 & 15.2 & 2 & \\
\hline & Tomato & 467 & 81.1 & 10.4 & 3 & \\
\hline & Cabbage & 391 & 65.9 & 8.47 & 4 & \\
\hline & Chilli & 467 & 43.2 & 5.56 & 5 & \\
\hline & Peas & 239 & 34.1 & 4.38 & 6 & \\
\hline & Bottle gourd & 234 & 27.8 & 3.57 & 7 & \\
\hline & Raddish & 254 & 27.1 & 3.48 & 8 & \\
\hline & $\begin{array}{l}\text { French } \\
\text { beans }\end{array}$ & 182 & 21.7 & 2.79 & 9 & \\
\hline & $\begin{array}{l}\text { Pointed } \\
\text { gourd }\end{array}$ & 77.0 & 10.2 & 1.98 & 10 & \\
\hline & Others & 980 & 135 & 17.5 & $11-111$ & \\
\hline \multirow[t]{12}{*}{ Zaid } & Cauliflower & 1,550 & 297 & 15.1 & 1 & \\
\hline & Eggplant & 1,290 & 214 & 10.9 & 2 & \\
\hline & Tomato & 1,040 & 211 & 10.8 & 3 & \\
\hline & Bottle gourd & 1,460 & 202 & 10.3 & 4 & \\
\hline & $\begin{array}{l}\text { Pointed } \\
\text { gourd }\end{array}$ & 738 & 109 & 5.56 & 5 & \\
\hline & Cabbage & 374 & 89.2 & 4.56 & 6 & $\begin{array}{l}\text { Table A3. } \\
\text { The seasonal }\end{array}$ \\
\hline & Chilli & 771 & 70.1 & 3.59 & 7 & composition of the top \\
\hline & Cucumber & 475 & 66.7 & 3.41 & 8 & ten fruits and \\
\hline & Carrot & 190 & 62.5 & 3.20 & 9 & vegetables aggregated \\
\hline & Raddish & 569 & 61.5 & 3.13 & 10 & by Loop between 1st \\
\hline & Others & 4,290 & 573 & 29.5 & $11-121$ & January 2016 and 20 th \\
\hline & & & & & (continued) & $\begin{array}{r}\text { September } 2018 \\
\text { (142 weeks) }\end{array}$ \\
\hline
\end{tabular}


JADEE 12,2

\begin{tabular}{|c|c|c|c|c|c|}
\hline Season & Crop & $\begin{array}{c}\text { Average } \\
\text { transactions per } \\
\text { week }\end{array}$ & $\begin{array}{l}\text { Average quantity } \\
\text { (tonnes/week) }\end{array}$ & $\begin{array}{c}\text { Proportion of } \\
\text { seasonal quantity }(\%)\end{array}$ & $\begin{array}{l}\text { Quantity } \\
\text { rank }\end{array}$ \\
\hline \multirow[t]{11}{*}{ Kharif } & Bottle gourd & 774 & 118 & 24.7 & 1 \\
\hline & $\begin{array}{l}\text { Pointed } \\
\text { gourd }\end{array}$ & 447 & 68.0 & 14.2 & 2 \\
\hline & Okra & 670 & 52.0 & 10.9 & 3 \\
\hline & Eggplant & 313 & 49.3 & 10.3 & 4 \\
\hline & $\begin{array}{l}\text { Sponge } \\
\text { gourd }\end{array}$ & 384 & 33.8 & 7.07 & 5 \\
\hline & Bitter gourd & 187 & 18.6 & 3.90 & 6 \\
\hline & Long beans & 214 & 13.5 & 2.83 & 7 \\
\hline & Ivy gourd & 75.1 & 8.60 & 1.80 & 8 \\
\hline & Banana & 58.1 & 7.59 & 1.59 & 9 \\
\hline & Yam & 24.4 & 7.55 & 1.56 & 10 \\
\hline & Others & 978 & 102 & 21.2 & $11-97$ \\
\hline
\end{tabular}

Note(s): The seasons are as follows: "Rabi" - 15th October to 14th March; "Zaid" - 15th March to 14th June; "Kharif" - 15th June to 14th October. Therefore, over the period of data availability, there are 53.7 Rabi weeks,

Table A3. 39.4 Zaid weeks and 48.9 Kharif weeks. All values given to three significant figures where appropriate

\section{Corresponding author}

Gregory S. Cooper can be contacted at: g.s.cooper@sheffield.ac.uk

For instructions on how to order reprints of this article, please visit our website:

www.emeraldgrouppublishing.com/licensing/reprints.htm

Or contact us for further details: permissions@emeraldinsight.com 